\title{
ВПЛИВ КОМОРБІДНИХ ЗАХВОРЮВАНЬ НА АКТИВНІСТЬ ЕКЗОГЕННОГО ФАКТОРА VIII У ХВОРИХ НА ТЯЖКУ ФОРМУ ГЕМОФІЛІЇ
}

\author{
Авер'янов Є. В., Семеняка В. I. \\ ДУ «Інститут гематології та трансфузіологї НАМН України», \\ Київ, Україна
}

\section{Резюме}

Вступ. При проведенні замісної гемостатичної терапї хворим на гемофілію А (ГА) гемостазіологічний статус пацієнта може змінюватися внаслідок впливу препаратів фактора VIII (ФVIII) та інших чинників, зокрема супутніх захворювань та коморбідних станів.

Мета. Дослідити зміни активності фактора ФVIII (АФVIII) у пацієнтів з ГА на тлі гемофілічної поліартропатії та інших коморбідних чинників.

Матеріали і методи. Досліджено гемостазіологічні, клінічні та рентгенологічні параметри 100 хворих на тяжку форму ГА та 20 практично здорових осіб контрольної групи. Хворих було поділено на 2 групи: з проявами коморбідності група дослідження (ДГ), без проявів коморбідності - група порівняння (ГП). Усім хворим вводили препарат ФVIII у дозі 50 МО/кг маси тіла. Оцінювали АФVІІІ: до введення (А0), через 0,5 або 1 год. після введення (максимальну активність (МА)), активність через 48 год. після введення (А48).

Результати. До введення препарату ФVIII після «відмивного періоду» АФVІІІ у більшості підгруп АО становила менше 1 МО/дл. Простежувалася тенденція до збільшення АФVIII із збільшенням стадії артропатії. У пацієнтів із гепатитами, як у підгрупах ДГ1, ДГ2, ДГЗ так $i$ в иілому значення МА були достовірно меншими від показника ГП. Серед пацієнтів із патологією печінки спостерігалася достовірна внутрішньогрупова варіація МА. Достовірної різниці параметру МА у пацієнтів із захворюваннями нирок та сериево-судинною патологією не спостерігалося. В підгрупах ДГ1-ДГ5 із печінковою коморбідністю спостерігалося достовірне зменшення показника А48 порівняно з ГП. У підгрупах пацієнтів із нирковою коморбідністю достовірної різниці з показником ГП не спостерігалося. У пацієнтів із серцево-судинною коморбідністю параметр А48 достовірно перевищував результат ГП. Активність ФVIII через 48 год. після введення у пацієнтів із нирковою коморбідністю в цілому достовірно перевищувала аналогічні значення у хворих із гепатитами та була меншою за досліджуваний параметр пацієнтів 3 серцево-судинною патологією.

Висновки. У пацієнтів дослідної групи з прогресуванням стадї гемофілічної поліартропатії збільшується АФVIII за досліджуваними параметрами. У 
пацієнтів із запальними захворюваннями печінки на тлі ранніх стадій гемофілічної поліартропатії споживання фактора VIII є більш значним, ніж при інших коморбідних станах. При сериево-судинній патології на тлі пізніх стадій гемофілічної поліартропатії відбувається значиме підвищення досліджуваних параметрів АФVIII. У пацієнтів із пієлонефритами та сечокам'яною хворобою після введення препаратів ФVIII досліджувані параметри активності ФVIII достовірно не відрізняються від аналогічних показників групи порівняння.

Ключові слова: гемофілія A, гемофілічна поліартропатія, препарати фактора VIII, коморбідність.

Конфлікт інтересів: автори заявляють про відсутність конфлікту інтересів.

Фінансування: дослідження не мало спонсорської підтримки.

\title{
THE EFFECT OF COMORBID DISEASES \\ ON THE ACTIVITY OF EXOGENOUS FACTOR VIII \\ IN PATIENTS WITH SEVERE HEMOPHILIA
}

\author{
Averianov Y. V., Semeniaka V. I. \\ SI «Institute of Haematology and Transfusiology of NAMS of Ukraine», Kyiv, Ukraine
}

\begin{abstract}
Introduction. During hemostatic replacement therapy (HRT) in patients with hemophilia $A(H A)$, the patient's hemostasis status may change due to exposure to factor VIII (FVIII) and other agents, including comorbidities and comorbid conditions.

Aim. To investigate changes in the activity of factor AFVIII in patients with HA on the background of hemophilic polyarthropathy and other comorbidities.

Materials and methods. Researched hemostasiological, clinical and radiological parameters of 100 patients with severe $H A$ and 20 healthy individuals of the control group. Patients were divided into 2 groups: with manifestations of comorbidity study group (SG), without manifestations of comorbidity comparison group (CG). All patients were administered the drug FVIII at the dose of $50 \mathrm{IU} / \mathrm{kg}$ body weight. AFVIII was evaluated: before administration (A0), 0.5 or 1 h after administration (maximum activity (MA)), activity 48 hours after administration (A48).

Results. Prior to the introduction of the drug FVIII after the washing period AFVIII AO in most subgroups was less than 1 IU/DL. There was a tendency to increase AFVIII with increasing stage of arthropathy. In patients with hepatic comorbidity in subgroups SG1, $S G 2, S G 3$ and in these patients in general, values of MA were significantly lower than $C G$. Significant intragroup variation of $M A$ was observed in patients with hepatic comorbidity. There was no significant difference between the MA parameter in patients with renal comorbidity and cardiovascular comorbidity. In subgroups SG1-SG5 with hepatic comorbidity there was a significant decrease in A48 compared with CG. In the
\end{abstract}


subgroups of patients with renal comorbidity, no significant difference with CG was observed. In patients with cardiovascular comorbidity, the A48 parameter significantly exceeded the CG result. The activity of FVIII A48 in patients with renal comorbidity in general significantly exceeded similar values in patients with hepatitis and was lower than the studied parameter in patients with cardiovascular pathology.

Conclusions. In patients of the study group with the progression of the stage of hemophilic polyarthropathy, the activity of the studied parameters of factor VIII increases. In patients with inflammatory liver disease in the early stages of hemophilic polyarthropathy, factor VIII intake is greater than in other comorbid conditions. At cardiovascular pathology against the background of late stages of hemophilic polyarthropathy there is a significant increase in the studied parameters of factor VIII activity. In patients with pyelonephritis and urolithiasis after administration of factor VIII drugs, the studied parameters of factor VIII activity do not differ significantly from similar indicators in the comparison group.

Keywords: hemophilia A, hemophilic polyarthropathy, drugs of factor VIII, comorbidity.

\section{Вступ}

Лікування пацієнтів із гемофілією А (ГА) та іiі ускладненнями залишається однією з важливих проблем сучасної гематології, що пов'язано 3 високим ступенем інвалідизації хворих, ризиком виникнення у них фатальних кровотеч, високою собівартістю терапії. ГА поділяють на тяжку, середню та легку форми гемофілії. Тяжка форма перебігу ГА спостерігається при активності фактора VIII (AФVIII) менше 1 MO/дл, середня при АФVIII 1-5 MO/дл, легка ->5-40 МО/дл. [1].

Найпоширенішим, патогенетично обгрунтованим, методом лікування ГА вважається замісна гемостатична терапія (ЗГТ) препаратами ФVIII, що може здійснюватися в профілактичному та симптоматичному («на вимогу») режимах. Вважається, що під впливом екзогенного ФVIII відбувається часткове або повне (залежно від дози) відновлення гемостатичних реакцій. При проведенні профілактичного лікування використовуються протоколи Malmõ, Utrecht або індивідуальні протоколи. Основним завданням профілактичного лікування хворих на ГА $є$ тимчасова трансформація тяжкої форми перебігу захворювання в легку та середню. Згідно з рекомендаціями ВОО3-ВФГ, лікування препаратами ФVIII має призначатися після проведення терапевтичного лікарського моніторингу та визначення фармакокінетики [2]. Це пов'язано з тим, що для цих засобів притаманна індивідуальна варіація фармакокінетичних параметрів, певні вікові особливості лікування, вузький терапевтичний діапазон. При лікуванні препаратами ФVIII гемостазіологічний статус хворого може змінюватися внаслідок впливу не лише ЗГТ, але й інших чинників, зокрема 
коморбідних захворювань. Дослідження, присвячені вивченню комор бідності, поєднаних та супутніх патологій у хворих на гемофілію, виокремлюють, як провідні, суглобову, печінкову, ниркову, серцево-судинну патологію [3].

Патологія суглобів, зокрема розвиток гемартрозів, $є$ специфічною ознакою ГА. Їх типова локалізація - синовіальні суглоби, серед яких колінні суглоби (КС) залучаються до патологічного процесу найчастіше. Також часто вражаються крововиливами ліктьові, кульшові та гомілковостопні суглоби [4].

У результаті низки патогенетичних процесів, у пацієнтів в суглобах формуються запально-дегенеративні зміни різного ступеня тяжкості, так звана гемофілічна артропатія (ГАП) [5]. Особливо дана проблема актуальна для пацієнтів дорослого віку в Україні через те, що тривалий час повноцінне профілактичне лікування було недоступним.

Згідно з нашими даними [6], під впливом ГАП, скоріше за все вгаслідок різної активності запальних процесів в суглобах на різних стадіях, існують варіації АФVIII в плазмі у пацієнтів. Але одночасний вплив на AФVIII різних коморбідних чинників у поєднанні з ГАП вивчений недостатньо.

Мета. Дослідити зміни АФVIII у пацієнтів з ГА на тлі ГАП та інших коморбідних чинників.

\section{Матеріали і методи}

Матеріалом дослідження були гемостазіологічні, клінічні та рентгенологічні параметри 100 хворих на ГА тяжкої форми перебігу та 20 практично здорових осіб контрольної групи (КГ). Вік пацієнтів становив 18 62 роки. Хворих було поділено на групу дослідження (ДГ) (88 осіб) та групу порівняння (ГП) (12 осіб). У жодного 3 пацієнтів на момент обстеження не визначалися імунні інгібітори, а активність фактора Віллебранда (ФВ) становила $(112,4 \pm 4,3) \%$ (показник КГ - $(108,2 \pm 4,9) \%)$. У двох осіб ДГ в анамнезі (понад 1,5 роки до даного дослідження) визначався транзиторний інгібітор у низькому титрі (менше 5 одиниць Бетезда). Показники протромбінового часу та вмісту фібриногену у пацієнтів ДГ та ГП не виходили за межі діапазону конрольних значень.

Для характеристики стадії артропатії використовували міжнародну рентгенологічну класифікацію W. D. Arnold - M. V. Hilgartner [7]. Відповідно до неї пацієнтів ДГ було поділено на 5 підгруп: ДГ1 - 10 осіб (І стадія), ДГ2 - 15 осіб (II стадія), ДГ3 - 23 особи (III стадія), ДГ4 26 осіб (IV стадія), ДГ5 - 14 осіб (V стадія). У пацієнтів ДГ спостерігалися 
інструментальні та лабораторні ознаки печінкової (40 осіб, 45,45 \%), ниркової (34 особи, 38,64 \%) та серцево-судинної (14 осіб, 15,91\%) патології. Коморбідним захворюванням печінки (печінкова коморбідність (ПК)) був хронічний гепатит внаслідок інфікування у попередній період життя вірусами гепатиту В або С. Пацієнти із цирозом печінки до ДГ не включалися в дослідження. Захворюваннями нирок (ниркова коморбідність (НК)) були пієлонефрити на тлі проявів сечокам'яної хвороби. Серцево-судинними захворюваннями (серцево-судинна коморбідність (ССК)) у пацієнтів ДГ були хронічна ішемічна хвороба серця (12 осіб) та стеноз мітрального клапану (2 особи). Хворі, у яких печінкова, ниркова та серцево-судинна патологія спостерігалися одночасно не включалися до дослідження. Діагностика проводилася клінічними, лабораторними та інструментальними методами під час планових госпіталізацій хворих.

Пацієнти ГП отримували з раннього дитинства профілактичне лікування препаратами ФVIII і не мали ознак ГАП та коморбідних чи супутніх захворювань.

До початку дослідження пацієнти ДГ та ГП не отримували препарати ФVIII понад 96 год. Препарат ФVIII плазмового походження з низьким вмістом ФВ уводився хворому натще у проміжку з 9:00 до 10:00 год. у дозі $50 \mathrm{MO} / к г$ маси тіла. Забір крові здійснювали за 0,5 год. до та через 0,5, 1, 48 год. після інфузії. В усі періоди визначали показники АФVIII. Дослідження проводили за допомогою коагулометра Helena C4 (Велика Британія). Усі реагенти та реактиви, котрі використовували, включно 3 контрольними плазмами, виробництва Siemens.

Оцінювали наступні параметри: АФVIII до введення (A0), максимальну активність (МА) (показник АФVIII через 0,5 або 1 год. після введення), AФVIII через 48 год. (А48) (48 год. - час досягнення активності близько $5 \mathrm{MO} /$ /л (час трансфомації індукованої екзогенним ФVIII легкої форми важкості ГА в середню)).

Усі дослідження системи гемостазу виконувалися згідно рекомендацій ВООЗ-ВФГ [8]. Обробку даних здійснювали методами варіаційної статистики з використанням t-критерію Стьюдента [9]. Достовірною вражалась різниця між середніми значеннями у випадках, коли рівень значущості $\mathrm{p}<0,05$.

Усі дослідження проводили з дотриманням основних положень Конвенції Ради Європи про права людини та біомедицину, Гельсінської декларації Всесвітньої медичної асоціації про етичні принципи проведення наукових медичних досліджень за участю людини та наказу МО3 України № 690 від 23.09.2009 p. 


\section{Результати та їх обговорення}

Результати дослідження представлено в таблицях 1-3.

Таблиця 1. Показники А0 обстежених паціснтів (МО/дл) (показник АФVIII КГ (112,42 $\pm 3,14)$ МО/дл, показник АО ГП (0,8 $\pm 0,01)$ МО/дл)

\begin{tabular}{|l|c|c|c|c|c|c|c|c|c|}
\hline \multirow{2}{*}{ Підгрупи } & \multicolumn{3}{|c|}{ ПК $(\mathbf{n = 4 0}$} & \multicolumn{3}{c|}{ НК $(\mathbf{n}=\mathbf{3 4 )}$} & \multicolumn{3}{c|}{ ССК (n=14) } \\
\cline { 2 - 11 } & $\mathbf{M}$ & $\mathbf{m}$ & $\mathbf{n}$ & $\mathbf{M}$ & $\mathbf{m}$ & $\mathbf{n}$ & $\mathbf{M}$ & $\mathbf{m}$ & $\mathbf{n}$ \\
\hline$Д Г 1, \mathrm{n}=7$ & 0,82 & 0,01 & 7 & - & - & - & - & - & - \\
\hline$Д Г 2, \mathrm{n}=16$ & 0,91 & 0,011 & 7 & 0,80 & 0,013 & 9 & - & - & - \\
\hline$Д Г 3, \mathrm{n}=17$ & 0,92 & 0,012 & 8 & 0,84 & 0,01 & 9 & - & - & - \\
\hline$Д Г 4, \mathrm{n}=25$ & 0,92 & 0,011 & 10 & 0,84 & 0,01 & 8 & 0,98 & 0,014 & 7 \\
\hline$Д Г 5, \mathrm{n}=23$ & $1,1^{1}$ & 0,01 & 8 & $0,97^{2}$ & 0,012 & 8 & $1,20^{3}$ & 0,01 & 7 \\
\hline Разом & $0,94^{4_{\mathrm{o}}}$ & 0,01 & 40 & $0,85^{4_{\mathrm{o}}}$ & 0,01 & 34 & $1,08^{4_{\mathrm{o}}}$ & 0,01 & 14 \\
\hline
\end{tabular}

Примітка. ${ }^{1}$ Достовірна різниця при ПК між показниками ДГ1 та іншими підгрупами та між ДГ5 і іншими підгрупами; ${ }^{2}$ достовірна різниця при НК між показниками ДГ2 та іншими підгрупами та між ДГ5 і іншими підгрупами; ${ }^{3}$ достовірна різниця при ССК між показниками ДГ 4 та ДГ $5,{ }^{4}$ достовірна різниця між показниками пацієнтів з різними коморбідними станами; ${ }^{\circ}$ Достовірна різниця показників ДГ та ГП.

До введення препарату ФVIII після «відмивного періоду» АФVIII у більшості підгруп А0 становила менше $1 \mathrm{MO} /$ дл (табл. 1). Це свідчить про тяжку форму перебігу ГА. Виключення становили хворі підгрупи ДГ5 із ПК та ССК. Можливо, це пов'язано з віковими модуляціями реакцій гемостазу (вік пацієнтів ДГ5 - 45-62 роки) та низькою активністю запальних процесів у суглобах. Крім того, простежувалася тенденція до збільшення АФVIII із збільшенням стадії артропатії. Так, у пацієнтів із ПК показник А0 ДГ5 був достовірно більшим у 1,34 рази, ніж показник ДГ1, при НК значення А0 ДГ5 перевищувало ДГ2 у 1,2 рази. При ССК відношення АФVIII між ДГ5 та ДГ4 також становило 1,2.

Зважаючи на те, що всі пацієнти ДГ та ГП зазвичай отримують профілактичну терапію препаратами ФVIII за протоколом Malmõ, подібні варіації не мають особливого клінічного значення, але при вимушеній перерві в інфузіях ФVIII, пацієнти ДГ5 мають більшу резистентність до крововиливів, ніж хворі інших підгруп.

Показник MA (табл. 2) при введенні препаратів ФVIII $€$ однією з найважливіших характеристик, яка показує рівень відновлення системи гемостазу. В даному дослідженні оптимальними вважали такі значення МА, 


\section{Таблиця 2. Показники МА обстежених паціснтів (МО/дл)

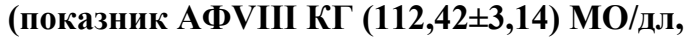 показник МА ГП $(104,31 \pm 1,88)$ МО/дл)}

\begin{tabular}{|l|c|c|c|c|c|c|c|c|c|}
\hline \multirow{2}{*}{ Підгрупи } & \multicolumn{3}{|c|}{ ПК (n=40) } & \multicolumn{3}{c|}{ НК (n=34) } & \multicolumn{3}{c|}{ CCK (n=14) } \\
\cline { 2 - 11 } & $\mathbf{M}$ & $\mathbf{m}$ & $\mathbf{n}$ & $\mathbf{M}$ & $\mathbf{m}$ & $\mathbf{n}$ & $\mathbf{M}$ & $\mathbf{m}$ & $\mathbf{n}$ \\
\hline$Д Г 1, \mathrm{n}=7$ & $87,25^{\circ}$ & 2,11 & 7 & - & - & - & - & - & \\
\hline$Д Г 2, \mathrm{n}=16$ & $91,44^{\circ}$ & 3,01 & 7 & 102,12 & 3,32 & 9 & - & - & \\
\hline$Д Г 3, \mathrm{n}=17$ & $94,42^{\circ}$ & 2,99 & 8 & 105,62 & 3,21 & 9 & - & - & \\
\hline$Д Г 4, \mathrm{n}=25$ & $104,67^{123}$ & 2,12 & 10 & 104,25 & 4,06 & 8 & 110,34 & 3,71 & 7 \\
\hline$Д Г 5, \mathrm{n}=23$ & $102,17^{12}$ & 2,23 & 8 & 103,82 & 3,51 & 8 & 112,42 & 2,94 & 7 \\
\hline Разом & $96,00^{\circ}$ & 2,48 & 40 & 103,91 & 3,45 & 34 & $111,82^{4}$ & 2,52 & 14 \\
\hline
\end{tabular}

Примітка. ${ }^{1}$ Достовірна різниця при ПК між показниками ДГ1 та ДГ4 і ДГ5; ${ }^{2}$ достовірна різниця при ПК між показниками ДГ2 та ДГ4 і ДГ5; 3 достовірна різниця при ПК між показниками ДГ3 та ДГ4, ${ }^{4}$ достовірна різниця між показниками пацієнтів з ПК та ССК; ${ }^{\circ}$ достовірна різниця з показником ГП.

які достовірно не відрізнялися від показника ГП. Цього не спостерігалося лише у пацієнтів із ПК у підгрупах ДГ1, ДГ2, ДГз та у пацієнтів із ПК в цілому, де МА була меншою аналогічного параметру ГП, відповідно, у 1,2; 1,5; 1,1 та 1,08 рази. Серед пацієнтів з ПК спостерігалася достовірна внутрішньогрупова варіація МА. Показник ДГ4 у них був більшим за МА ДГ1, ДГ2 та ДГ3 в 1,2; 1,4 та 1,1 рази відповідно, а аналогічне спів відношення між ДГ5 та ДГ1, ДГ2 і ДГ3 становило 1,17; 1,11, та 1,08. Параметр MA реєстрували через 0,5 год. після введення дози ФVIII. Слід відмітити, що через 1 год. після введення AФVIII в усіх випадках спостереження достовірно не відрізнялася від тієї, котра спостерігалася через 0,5 год.

Отримані дані свідчать про те, що у пацієнтів на більш ранніх стадіях ГАП на тлі ПК відновлення АФVIII за допомогою екзогенного ФVIII відбувається не повністю. Причини цього явища полягають не лише в більш активному перебігу запальних процесів, але й у впливі ПК. Такий висновок можна зробити, виходячи з того, що при НК в підгрупах ДГ2 та ДГЗ достовірного зменшення AФVIII не відбувалося порівняно як з ГП, так і з ДГ4 і ДГ5. Достовірної різниці параметру МА у пацієнтів із НК та ССК не спостерігалося, але звертає на себе увагу той факт, що у хворих 3 ССК рівень відновлення ФVIII недостовірно перевищував показник ГП. Можливо, це є наслідком вікових змін в організмі хворих [10].

Згідно до протоколу Malmõ інфузї ФVIII рекомендується проводити у дозі 25-40 MO/кг маси тіла тричі на тиждень. Тобто період між уведен- 
нями має становити 56 год. На практиці при проведенні профілактичного лікування хворі застосовують препарати ФVIII 3 періодичністю 4872 години залежно від свого стану та інтенсивності фізичних навантажень, котрі здійснювалися або будуть здійснюватися паціснтом.

\section{Таблиця 3. Показники М48 обстежених паціснтів (МО/дл) (показник АФVIII КГ (112,42 $\pm 3,14)$ МО/дл, показник М48 ГП $(6,42 \pm 0,13)$ МО/дл)}

\begin{tabular}{|l|c|c|c|c|c|c|c|c|c|}
\hline \multirow{2}{*}{ Підгрупи } & \multicolumn{3}{|c|}{ ПК (n=40) } & \multicolumn{3}{c|}{ НК (n=34) } & \multicolumn{3}{c|}{ CСК (n=14) } \\
\cline { 2 - 11 } & $\mathbf{M}$ & $\mathbf{m}$ & $\mathbf{n}$ & $\mathbf{M}$ & $\mathbf{m}$ & $\mathbf{n}$ & $\mathbf{M}$ & $\mathbf{m}$ & $\mathbf{n}$ \\
\hline ДГ1, $\mathrm{n}=7$ & $2,12^{\mathbf{o}}$ & 0,22 & 7 & - & - & - & - & - & - \\
\hline$Д Г 2, \mathrm{n}=16$ & $2,11^{\mathbf{o}}$ & 0,24 & 7 & 6,16 & 0,55 & 9 & - & - & - \\
\hline$Д Г 3, \mathrm{n}=17$ & $4,45^{12 \mathbf{o}}$ & 0,38 & 8 & 6,25 & 0,46 & 9 & - & - & - \\
\hline$Д Г 4, \mathrm{n}=25$ & $4,72^{12 \mathrm{o}}$ & 0,32 & 10 & 7,28 & 0,56 & 8 & $9,13^{\circ}$ & 0,71 & 7 \\
\hline$Д Г 5, \mathrm{n}=23$ & $4,65^{12 \mathrm{o}}$ & 0,36 & 8 & 7,24 & 0,44 & 8 & $9,24^{\mathbf{0}}$ & 0,76 & 7 \\
\hline Разом & $3,63^{\mathbf{0}}$ & 0,39 & 40 & $6,87^{3}$ & 0,41 & 34 & $9,16^{34_{0}}$ & 0,74 & 14 \\
\hline
\end{tabular}

Примітка. ${ }^{1}$ Достовірна різниця при ПК між показниками ДГ1 та ДГз, ДГ4 і ДГ5; ${ }^{2}$ достовірна різниця при ПК між показниками ДГ2 та ДГЗ, ДГ4 і ДГ5; ${ }^{3}$ достовірна різниця між показниками пацієнтів із пацієнтів з ПК та НК і ССК;

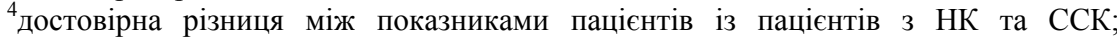
одостовірна різниця з показником ГП.

Тому показник A48 (табл. 3) відображує активність ФVIII на початку періоду повторної інфузії. Вкрай важливо розуміти вплив на цей показник ГАП та коморбідних станів для того, щоб не допустити трансформацію ГА в тяжку форму перебігу. Отримані дані свідчать, що в підгрупах ДГ1ДГ5 з ПК спостерігалося достовірне зменшення показника А48 порівняно 3 ГП, відповідно у 3,$0 ; 3,0 ; 1,4 ; 1,4 ; 1,4$ рази та в 1,4 рази у групі в цілому. У підгрупах пацієнтів із НК достовірної різниці з показником ГП не спостерігалося. На відміну від цього, у пацієнтів із ССК досліджуваний параметр достовірно перевищував результат ГП у 1,4 рази в підгрупах ДГ4 та ДГ5, що, можливо, теж пов'язано із віковими змінами системи гемостазу. При цьому АФVIII А48 у пацієнтів із НК в цілому достовірно перевищувала аналогічні значення у хворих з ПК в 1,9 рази та була меншою за параметр, що досліджувався, у пацієнтів з ССК у 1,3 рази.

Необхідно зауважити, що отримані дані не можна вважати остаточними, оскільки кількість спостережень в кожній підгрупі недостатня. 
Поділ пацієнтів із ГА за формами важкості, особливо при тяжкій та середній, може не відповідати реальній клінічній картині. Це пов'язують із індивідуальними особливостями замісної гемостатичної терапії: якщо пацієнт отримував повноцінну профілактику препаратами ФVIII 3 дитинства, то стан його суглобово-м'язової системи $є$ задовільним, без схильності до рецидивів крововиливів. Крім того необхідно враховувати варіабельність результатів лабораторного тестування ФVIII [11]. Додатковими чинникам впливу на AФVIII екзогенного походження вважається вік та група крові пацієнта, а також можливе виникнення імунного інгібітора. Не виключено, що існують і інші чинники [12].

Відомо, що при печінковій патології може зменшуватися активність ФВ за рахунок синтезу малофункціональних молекул цього протеїну [13]. Але усім пацієнтам попередньо проводили визначення активності ФВ і вона була в межах нормальних значень. У осіб без вроджених патологій гемостазу при наявності вірусного гепатиту спостерігається зменшення активності антитромбіну III та протеїну C [14]. Проте хронічні захворювання печінки призводять до значного посилення фібринолітичних процесів [15]. Не виключено, що інтенсивне споживання ФVIII в зоні запалення та підвищення фібринолітичного потенціалу крові, спровоковане печінковою патологією, призводять до зниження досліджуваних параметрів A0, МА та А48 в підгрупах ДГ1 та ДГ2 при ПК.

У осіб без гемофілії вважається доведеним зв'язок між процесами запалення та протромботичними змінами в системі гемостазу [16]. Порушення функції нирок не є виключенням, але вплив запальних процесів на систему гемостазу у хворих на гемофілію дещо відрізняється. Передусім, організм хворого на гемофілію не має власного резерву для компенсації втраченого в зоні запалення ФVIII. При НК, як і при ПК, відбувається зниження активності основного природного інгібітора ФVIII протеїна $\mathrm{C}$ та його кофактора протеїна $\mathrm{S}$ [17]. На відміну від ПК, при сечокам'яній хворобі спостерігається пригнічення фібринолітичної активності [18]. Тобто споживання ФVIII та пригнічення гемостатичних реакцій продуктами фібринолізу менш виражене. Перебіг ССК може супроводжуватися підвищенням АФVIII, ФВ та інтенсифікацією протромботичних реакцій. При цьому ризик розвитку фатальних тромботичних ускладнень при ГА значно менший [19]. Отримані в цьому дослідженні дані підтверджують те, що дозування препаратів ФVIII при проведенні профілактичного лікування має базуватися на грунтовному аналізі можливого впливу різних коморбідних чинників на систему гемостазу [20] та АФVIII на різних етапах профілактичного лікування. У пацієнтів із 
нетиповою відповіддю на застосування екзогенного ФVIII необхідно застосовувати індивідуальні протоколи профілактичного та симптоматичного лікування.

Корекція впливу коморбідних захворювань на систему гемостазу у хворих на гемофілію сприяє покращенню якості життя, зменшенню інвалідизації, поліпшенню фізичної та соціальної реабілітації.

\section{Висновки}

1. Показано, що у всіх пацієнтів групи дослідження 3 прогресуванням стадії гемофілічної поліартропатії збільшується активність фактора VIII за параметрами, котрі досліджувались.

2. Доведено, що у пацієнтів із запальними захворюваннями печінки на тлі ранніх стадій гемофілічної поліартропатії споживання фактора VIII $\epsilon$ більш значним, ніж при інших досліджуваних коморбідних станах.

3. Показано, що при серцево-судинній патології на тлі пізніх стадій гемофілічної поліартропатії відбувається значиме підвищення досліджуваних параметрів активності фактора VIII.

4. Доведено, що у пацієнтів із пієлонефритом та сечокам'яною хворобою після введення препаратів фактора VIII досліджувані параметри активності фактора VIII достовірно не відрізнялись від аналогічних показників у групі порівняння.

\section{Література}

1. Видиборець С. В., Дерпак Ю. Ю., Попович ЮЮ. Гемофілія. Семейная медицина. 2018, 6, 61-66.

2. Srivastava A, Santagostino E, Dougall A et al. WFH Guidelines for the Management of Hemophilia, 3rd edition. Haemophilia. 2020, 26(Suppl6), 1-158. https://doi.org/10.1111/hae.14046

3. Kempton CL, Makris M, Holme PA. Management of comorbidities in haemophilia. Haemophilia. 2021, 27 (Suppl. 3), 37-45.

4. Rodriguez-Merchan EC Musculo-skeletal manifestations of haemophilia. Blood Reviews, 2016, 30(5), 401-409

5. Nacca CR Hemophilic Arthropathy. Orthopedics. 2017, 40(6), 940-946.

\section{Refereces}

1. Vydyborets`S.V., Derpak YU.YU., Popovych YUYU. Hemofiliya. Semeynaya meditsina. 2018, 6, 61-66.

2. Srivastava A, Santagostino E, Dougall A et al. WFH Guidelines for the Management of Hemophilia, 3rd edition. Haemophilia. 2020, 26(Suppl6), 1-158. https://doi.org/10.1111/hae.14046

3. Kempton CL, Makris M, Holme PA. Management of comorbidities in haemophilia. Haemophilia. 2021, 27 (Suppl. 3), 37-45.

4. Rodriguez-Merchan EC Musculoskeletal manifestations of haemophilia. Blood Reviews, 2016, 30(5), 401-409

5. Nacca CR Hemophilic Arthropathy. Orthopedics. 2017, 40(6), 940-946. 
6. Семеняка BI, Авер'янов $\mathrm{CB}$, Аношина МЮ, Ющенко ПВ. Дослідження фармакокінетики препаратів фактора VIII донорського походження у хворих на гемофілію А iз артритами колінних суглобів. Гематологія і переливання крові. 2015, 38, 282-289.

7. Kilcoyne RF, Lundin B, Pettersson $\mathrm{H}$. Evolution of the imaging tests in hemophilia with emphasis on radiography and magnetic resonance imaging. Acta Radiol., 2006, 47(3), 287296.

8. Kitchen S, McCraw A, Echenagucia M. Diagnosis of Hemophilia and Other Bleeding Disorders A LABORATORY MANUAL Second Edition. World Federation of Hemophilia, 2010, 150.

9. Лапач CH, Чубенко АВ, Бабич ПН Статистические методы в медикобиологических исследованиях с использованием Excel. Морион. 2000, 320.

10. Stettler GR, Moore EE, Moore HB et al. Variability in international normalized ratio and activated partial thromboplastin time after injury are not explained by coagulation factor deficits. The journal of trauma and acute care surgery. 2019, 87(3), 582.

11. Ogiwara K, Swystun LL, Paine AS et al. Factor VIII pharmacokinetics associates with genetic modifiers of VWF and FVIII clearance in an adult hemophilia A population. JTH. 2021, 19(3), 654-663.

12. Tripodi A, Chantarangkul V, Novembrino $\mathrm{C}$, Peyvandi F. Advances in the treatment of hemophilia: implications for laboratory testing. Clinical chemistry. 2019, 65(2), 254-262.
6. Semeniaka VI, Averianov YeV, Anoshyna MYu, Yushchenko PV. Study of pharmacokinetics of factor VIII preparations of donor origin in patients with hemophilia A with arthritis of the knee. Hematolohiya i perelyvannya krovi. 2015, 38, 282-289.

7. Kilcoyne RF, Lundin B, Pettersson $\mathrm{H}$. Evolution of the imaging tests in hemophilia with emphasis on radiography and magnetic resonance imaging. Acta Radiol., 2006, 47(3), 287296.

8. Kitchen S, McCraw A, Echenagucia M. Diagnosis of Hemophilia and Other Bleeding Disorders A LABORATORY MANUAL Second Edition. World Federation of Hemophilia, 2010, 150.

9. Lapach SN, Chubenko AV, Babich PN Statisticheskiye metody $\mathrm{v}$ mediko-biologicheskikh issledovaniyakh s ispol'zovaniyem Excel. Morion. 2000, 320.

10. Stettler GR, Moore EE, Moore HB et al. Variability in international normalized ratio and activated partial thromboplastin time after injury are not explained by coagulation factor deficits. The journal of trauma and acute care surgery. 2019, 87(3), 582.

11. Ogiwara K, Swystun LL, Paine AS et al. Factor VIII pharmacokinetics associates with genetic modifiers of VWF and FVIII clearance in an adult hemophilia A population. JTH. 2021, 19(3), 654-663.

12. Tripodi A, Chantarangkul V, Novembrino $\mathrm{C}$, Peyvandi F. Advances in the treatment of hemophilia: implications for laboratory testing. Clinical chemistry. 2019, 65(2), 254-262. 
13. Turecek PL, Johnsen JM, Pipe SW et al Biological mechanisms underlying inter-individual variation in factor VIII clearance in haemophilia. Haemophilia. 2020, 26(4), 575-583.

14. Морозов ЮА, Медников РВ, Чарная МА. Нарушения системы гемостаза при патологии печени и их диагностика. Геморрагические диатезы, тромбозы, тромбофилии. 2014, (1).

15. Abo-Elenein AM, Mabrouk MM, Abou-Saif $S$ et al Role of both protein $\mathrm{c}$ and antithrombin III as predictors of stage of liver disease in chronic viral hepatitis $\mathrm{B}$ or $\mathrm{C}$ infected patients. Endocrine, Metabolic \& Immune Disorders-Drug Targets (Formerly Current Drug Targets-Immune, Endocrine \& Metabolic Disorders). 2020, 20(1), 112-117.

16. von Meijenfeldt FA, Lisman T, Fibrinolysis in Patients with Liver Disease. Semin Thromb Hemost. 2021, 47(05), 601-609. doi: $10.1055 / \mathrm{s}-0040-1718924$

17. Oikonomou E, Leopoulou M, Theofilis $\mathrm{P}$ et al. A link between inflammation and thrombosis in atherosclerotic cardiovascular diseases: Clinical and therapeutic implications. Atherosclerosis. 2020, 309, 16-26. doi: 10.1016/j.atherosclerosis.2020. 07.027

18. Al-Ghamdi MA, Huwait EA, Kumosani TA et al. Serum proteins C and $\mathrm{S}$ levels as early biomarkers for kidney dysfunction in hemophilic patients. African health sciences, 2018, 18(3), 681-688.

19. Клочков ВВ, Клочков АВ, Мясников КВ, Мягков ВВ. Система гемостаза крови и мочи в патогенезе
13. Turecek PL, Johnsen JM, Pipe SW et al Biological mechanisms underlying inter-individual variation in factor VIII clearance in haemophilia. Haemophilia. 2020, 26(4), 575-583.

14. Morozov YUA, Mednikov RV, Charnaya MA. Narusheniya sistemy gemostaza pri patologii pecheni i ikh diagnostika. Gemorragicheskiye diatezy, trombozy, trombofilii. 2014, (1).

15. Abo-Elenein AM, Mabrouk MM, Abou-Saif $\mathrm{S}$ et al Role of both protein $\mathrm{c}$ and antithrombin III as predictors of stage of liver disease in chronic viral hepatitis $\mathrm{B}$ or $\mathrm{C}$ infected patients. Endocrine, Metabolic \& Immune Disorders-Drug Targets (Formerly Current Drug Targets-Immune, Endocrine \& Metabolic Disorders). 2020, 20(1), 112-117.

16. von Meijenfeldt FA, Lisman T, Fibrinolysis in Patients with Liver Disease. Semin Thromb Hemost. 2021, 47(05), 601-609.

doi: 10.1055/s- 0040-1718924

17. Oikonomou E, Leopoulou M, Theofilis $\mathrm{P}$ et al. A link between inflammation and thrombosis in atherosclerotic cardiovascular diseases: Clinical and therapeutic implications. Atherosclerosis. 2020, 309, 16-26. doi: 10.1016/j.atherosclerosis.2020. 07.027

18. Al-Ghamdi MA, Huwait EA, Kumosani TA et al. Serum proteins $C$ and $\mathrm{S}$ levels as early biomarkers for kidney dysfunction in hemophilic patients. African health sciences, 2018, 18(3), 681-688.

19. Klochkov VV, Klochkov AV, Myasnikov KV, Myagkov VV. Sistema gemostaza krovi i mochi v 
мочекаменной болезни. Национальные проекты - приоритет развития здравоохранения регионов. 2019. 678-679.

20. Tuinenburg A et al. Cardiovascular disease in patients with hemophilia. JTH. 2009, 7(2), 247-254.

Стаття надійшла 16.08.2021

Контакти: siemleonv@gmail.com patogeneze mochekamennoy bolezni. Natsional'nyye proyekty - prioritet razvitiya zdravookhraneniya regionov. 2019. 678-679.

20. Tuinenburg A et al. Cardiovascular disease in patients with hemophilia. JTH. 2009, 7(2), 247-254. 